\title{
Review
}

\section{Sea Buckthorn (Hippophae rhamnoides L.): A Multipurpose Plant}

\author{
Thomas S.C. Li $\mathrm{i}^{1}$ and W.R. Schroeder ${ }^{2}$
}

Additional index words. Soil erosion, land reclamation, farmstead protection, nutritional and medicinal values

Summary. Sea buckthorn (H i ppophae rhamnoi des L .) is a multipurpose, hardy, deciduous shrub, an ideal plant for soil erosion control, land reclamation, wildlife habitat enhancement, and farmstead protection. It has high nutritional and medicinal values for humans. The majority of sea buckthorn research has been conducted in Asia and Europe. It is a promising new crop for $\mathbf{N}$ orth America, and recently it has attracted considerable attention by researchers, producers, and industry.

S ea buckthorn (H ippophae rhamnoides) is a hardy, deciduous shrub with yellow or orange berries (Fig. 1) (Bailey and Bailey, 1978), which has been used for centuries in Europe and Asia. In ancient G reece, leaves of sea buckthorn added to horse fodder was well reputed to result in weight gain and shiny hair; thus, the Latin name' $\mathrm{H}$ ippophae' meaning shining horse ( $\mathrm{Lu}$, 1992). Sea buckthorn occurs as a native plant distributed widely through-

${ }^{1} \mathrm{~A}$ gricultureand $\mathrm{A}$ gri-Food $\mathrm{C}$ anada, $\mathrm{R}$ esearch $\mathrm{C}$ entre, Summerland, B.C., Canada VOH 1 ZO.

${ }^{2}$ A griculture and A gri-Food Canada, P.F.R.A., Shelterbelt C entre, I ndian H ead, Saskatchewan, Canada SOG $2 \mathrm{~K} 2$.

Contribution no. 971.

The cost of publishing thispaper was defrayed in part by the payment of page charges. U nder postal regulations, this paper therefore must be hereby marked advertisement solely to indicate thisfact. out temperate zones between $27^{\circ}$ and $69^{\circ} \mathrm{N}$ latitude and $7^{\circ} \mathrm{W}$ and $122^{\circ} \mathrm{E}$ longitude (Pan et al., 1989; Rousi, 1971) including China, Mongolia, Russia, Great Britain, France, Denmark, N etherlands, Germany, Poland, Finland, Sweden, and N orway (Fig. 2) (Wahlberg and Jeppsson, 1990; Yao and T igerstedt, 1995). D uring the last decade, it has attracted considerable attention from researchers around the world, and recently in N orth America, mainly for its nutritional and medicinal value.

Sea buckthorn can be cultivated, but fails to set fruit, at an altitude of 3900 m (Rousi, 1971). I n Russia, large, native populations grow at altitudes of 1200 to $2000 \mathrm{~m}$ abovesealevel (E liseev and Fefelov, 1977). It can withstand temperatures from -43 to $40{ }^{\circ} \mathrm{C}(\mathrm{Lu}$, 1992). Sea buckthorn is considered to be drought resistant ( $\mathrm{H}$ einze and
Fiedler, 1981; Kondrashov and Sokolova, 1990); however, most natural populationsgrow in areas receiving 400 to $600 \mathrm{~mm}$ of annual precipitation. M yakushko et al. (1986) recommended that sea buckthorn not be grown on dry soils, and Lu (1992) noted the need for irrigation in regions receiving $<400 \mathrm{~mm}$ of rainfall per year. Somespeciesor subspecies of sea buckthorn can endure inundation but cannot be grown on heavy, waterlogged soils (M yakushko et al., 1986), although they take up water rapidly (H einze and Fiedler, 1981). Sea buckthorn develops an extensive root system rapidly and is therefore an ideal plant for preventing soil erosion (Cireasa, 1986; Yao and Tigerstedt, 1994). It also has been used in land reclamation (E gyed-Balint and T erpo, 1983; Kluczynski, 1979; Schroeder and Yao, 1995) for its ability to fix nitrogen and conserve other essential nutrients (Akkermans et al., 1983; Andreeva et al., 1982; Dobritsa and N ovik, 1992)

Seabuckthorn wasimported originally into C anada from Russia to the $M$ orden R esearch Station, Agriculture and Agri-Food Canada, M orden, $M$ anitoba, in 1938 (D avidson et al., 1994). Plantingswerelimited to ornamental landscapes, except in the provinces of Saskatchewan and M anitoba. The Shelterbelt Centre of the Prairie Farm Rehabilitation Administration (PFRA) of Agriculture and Agri-F ood C anada (Indian H ead, Saskatchewan) have been growing sea buckthorn for 30 years. It is one of the hardiest and most adaptable woody plants used in prairie conservation programs (Schroeder, 1988). More than one million seedlings have been distributed, and more than 250,000 mature fruit-producing plants grow on the prairies for enhancement of wildlife habitat, farmstead protection (Pearson and Rogers, 1962), erosion control (C ireasa, 1986), and marginal land reclamation (Balint et al., 1989; Kluchzynski, 1989; Schroeder, 1990).

Sea buckthorn can be used for many purposes (Fig. 3) and, thus, has considerable economic potential. A natural seabuckthorn habitat can yield 750 to $1500 \mathrm{~kg} \cdot \mathrm{ha}^{-1}$ of berries ( $\mathrm{Lu}$, 1992), shelterbelt plantings 4 to 5 t. ha ${ }^{-1}$ (Schroeder and Yao, 1995), and orchard plantings, up to $10 \mathrm{t} \cdot \mathrm{ha}^{-1}$ (C. $M C L$ oughlin, personal communication). The vitamin $C$ and $E$ contents 


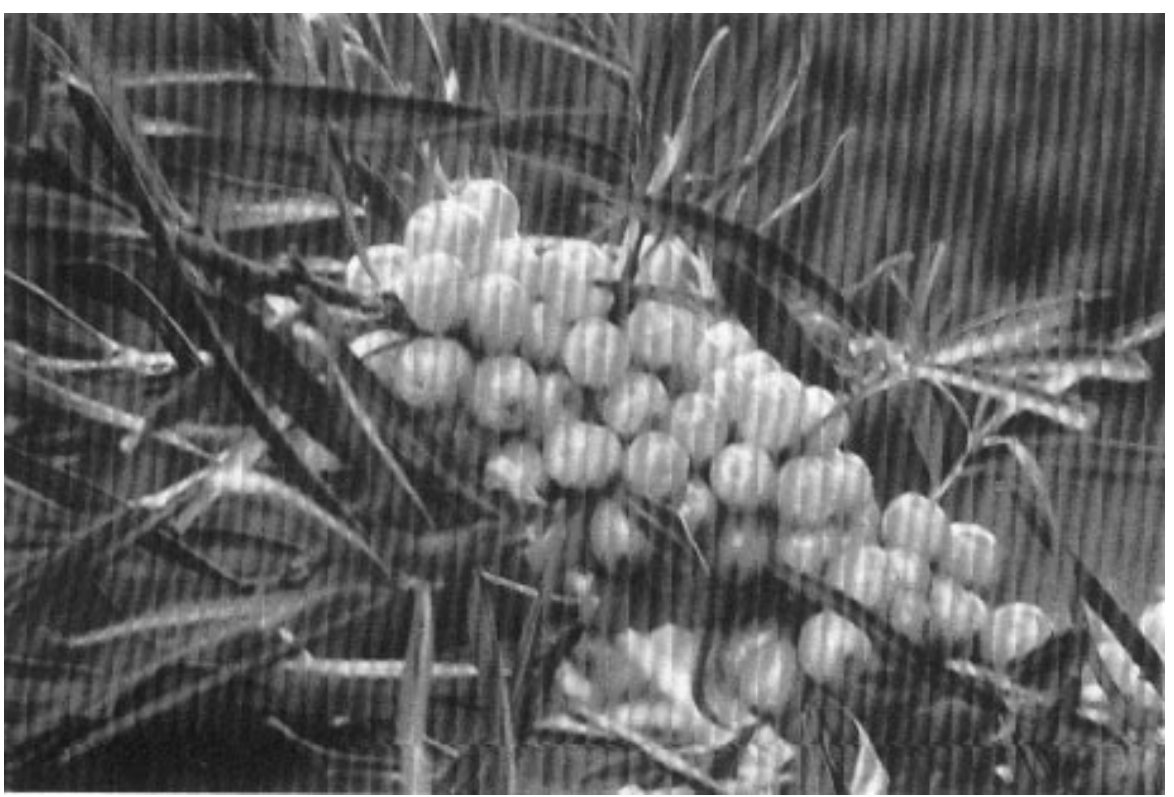

Fig. 1. Sea buckthorn berries.

are as high as 600 and $160 \mathrm{mg} / 100 \mathrm{~g}$ of fruit, respectively (Bernath and Foldesi, 1992). I ts pulp and seedscontain essential oil important for its medicinal value, such as superoxide dismutase activity in mice, and it has enhanced the activity of NK cells in tumor-bearing mice (C hen, 1991; $D$ ai et al., 1987; D egtyareva et al., 1991).

\section{Taxonomy}

$\mathrm{H}$ ippophae belongs to the family Elaeagnaceae. ArneR ousi (1971) classified $\mathrm{H}$ ippophae $(2 \mathrm{n}=24)$ into three species based on morphological variations: $H$. rhamnoides L., H . salicifolia D. Don, and H. tibetana Schlecht. $\mathrm{H}$ ippophae rhamnoides was divided further into ninesubspecies: carpatica, caucasica, gyantsensis mongolica, sinensis, turkestanica, yunnanensis, rhamnoides, and fluviatilis Rousi. Liu and $\mathrm{He}$ (1978) described a fourth species, H. neurocarpa Liu \& He, found on the $Q$ inghai-Xizang plateau of China. These classifications were accepted generally by Lian (1988), but taxonomists still disagree on the precise classification of the genus.

\section{Natural distribution}

Sea buckthorn is native to Europe and Asia (Fig. 2). The total area of sea buckthorn in China, Mongolia, and Russia is about 810,000 ha of natural stands and 300,000 to 500,000 ha planted (Sun, 1995). N atural sea buckthorn stands are also widespread in E u- rope- on river banks and coastal dunes along the Baltic Coast of Finland, Poland, and Germany (Biswas and Biswas, 1980; K luczynski, 1989; Rousi, 1971) and on the western coast and along the Gulf of Bothnia in Sweden. In Asia, sea buckthorn isdistributed widely throughout the $\mathrm{H}$ imalayan regions including India, Nepal, and Bhutan and in the northern parts of Pakistan and Afghanistan (Lu, 1992).

\section{Description}

Seabuckthorn isadeciduous, dioeciousshrub, usually spinescent, reaching 2 to $4 \mathrm{~m}$ in height. I t has brown or black rough bark and a thick grayishgreen crown. L eaves are alternate, narrow, and lanceolate with a silver-gray color on the upper side (Synge, 1974). This calcicolous species tolerates low temperatures, high soil pH of 8.0, and salt spray (Bond, 1983). The plant's extensive root system is capable of holding the soil on fragile slopes. Sea buckthorn can be planted in marginal soils due to its symbiotic association with nitrogen-fixing actinomycetes (Akkermans et al., 1983; D obritsa and N ovik, 1992). Roots of sea buckthorn also are able to transform insoluble organic and mineral matter in the soil into more soluble states ( $L u, 1992)$. The plant rapidly spreads by rhizomatous roots, and will quickly colonize adjacent areas.

The sex of seedlings cannot be ascertained until they start to flower (Synge, 1974). Flower budsareformed mostly on 3-year-old wood, differentiated during the previous growing sea- son (Bernath and Foldesi, 1992). The male inflorescence consists of four to six apetalousflowers. Pollen isreleased in large quantities when the air temperature reaches 6 to $10^{\circ} \mathrm{C}$. The female inflorescence usually consists of one single apetalous flower with one ovary and one ovule. The plant depends entirely on the wind for pollination: neither the male nor the female flowers have nectaries and do not attract insects.

\section{Cultural management}

Sea buckthorn normally is transplanted or directly seeded in thespring. Best growth occurs in deep, well drained, sandy loam soil with ample organic matter (Wolf and Wegert, 1993). In arid or semiarid areas, water must be supplied for establishment.

Information in the literature regarding the cultivation of sea buckthorn is limited. In Saskatchewan, Canada, seedlings planted in shelterbelts are often under stress due to lack of proper management. For commercial production in orchard-like plantations, cultural management is clearly important. Good growing conditionsproducehigher yield and goodquality fruit (Walhberg and J eppsson, 1990; Wolfe and Wegert, 1993). C rop management of sea buckthorn should include fertilization and cultural practices such as spacing, pruning, irrigation, and weed control.

Soll texture and PH. In its natural environment, sea buckthorn plants are found on slopes, riverbanks, and seashores. Soil acidity and alkalinity, except at extreme levels, are not limiting factors. In China, plants have been found in soils ranging from $\mathrm{pH}$ 5.5 to 8.3, although Lu (1992) reported that sea buckthorn thrives best at pH 6 to 7. Wolf and Wegert (1993) reported actinomycetes, which have a low tolerance for acid soil, living in symbiosis with sea buckthorn, which has a favorable range of $\mathrm{pH} 5.4$ to 7.0.

Sea buckthorn is salt tolerant. An unconfirmed report indicated that $0.15 \% \mathrm{NaCl}$ added to the growing media increased the growth of some varieties of sea buckthorn in the laboratory ( $L$ u, 1992). Furthermore, soaking seeds for $24 \mathrm{~h}$ in $0.15 \% \mathrm{NaCl}$ before sowing increased the number of vigorous seedlings.

Precipitation and soll molsTURE. M ost natural populations of sea buckthorn grow in areas receiving an- 
nual precipitation of 400 to $600 \mathrm{~mm}$. For economic reasons, sea buckthorn orchards should be restricted to areas receiving a minimum of $400 \mathrm{~mm}$ of annual precipitation. Sea buckthorn is sensitive to severe soil moisture deficits, especially in spring when plants are flowering and young fruit are beginning to develop. U nder extended drought situations (i.e., >30 centibars), young fruit may dehydrate or abscise (Lu, 1992). Buglova (1978) reported that weather conditions, especially precipitation, could affect fruit weight. In Belarus Academy of Science, Russia, Garanovich (1995) reported that irrigation was necessary during dry growing seasons. I n an unconfirmed report, Lu (1992) indicated that the minimum soil moisture levels needed to cultivate sea buckthorn in medium clay loam, heavy clay, slightly sandy soil, and sandy loam were $70 \%, 80 \%$, $60 \%$, and $65 \%$ to $70 \%$, respectively. Li (1990) reported that crown diameter and fruit yield increased $56 \%$ and $47 \%$, respectively, in an irrigated plot with
$>70 \%$ soil moisture compared with a nonirrigated plot with soil moisture of $50 \%$ to $60 \%$. These reports suggest that irrigation may be beneficial during periods of extended drought, especially during flowering and fruit development stages.

SoIL FerTiLity. M ost of the soil fertility research on sea buckthorn was conducted in Russia and indicates that sea buckthorn, like any other crop, requires adequate soil nutrients for a high yield of good-quality fruit. Sea buckthorn responds well to phosphorus fertilizer, especially in soils low in phosphorus. A pplication of 600 to 800 $\mathrm{kg} \cdot \mathrm{ha}^{-1}$ of calcium superphosphate plowed deeply into the soil has been recommended (A. Bruvelis, personal communication). Garanovich (1995) reported that, in Belarus, a single winter top dressing with mineral fertilizers $100 \mathrm{~N}-200 \mathrm{P}_{2} \mathrm{O}_{5}-100 \mathrm{~K}_{2} \mathrm{O} \quad\left(\mathrm{kg} \cdot \mathrm{ha}^{-1}\right)$ improved fruit size, yield, and quality. M artemyanov and Khromova (1985) indicated that best growth was obtained by applying peat compost at 60 $\mathrm{t} \cdot \mathrm{ha} \mathrm{a}^{-1}$ and $50 \mathrm{~kg} \cdot \mathrm{ha}^{-1}$ each of $\mathrm{N}, \mathrm{P}_{2} \mathrm{O}_{5}$ and $\mathrm{K}_{2} \mathrm{O}$. In Siberia, 5-year total fruit yield increased by $23 \%$ when $\mathrm{N}, \mathrm{P}_{2} \mathrm{O}_{5}$, and $\mathrm{K}_{2} \mathrm{O}$ at $60 \mathrm{~kg} \cdot \mathrm{ha}^{-1}$ each were applied to a black calcareous soil (Predeina, 1987). M ontpetit and Lalonde (1988) cautioned that nitrogen fertilization can adversely affect root nodulation and it delays the development of nodules after inoculation with Frankia. Similar results have been shown for other nitrogen-fixing woody plants (M ackay et al., 1987). M ishulina (1976) reported that foliar sprays with micronutrients- $\mathrm{Cu}, \mathrm{M} \mathrm{O}$, $M n, I, B, C o$, and $Z n$-increased fruit weight by up to $34.5 \%$ In China, application of 100 to $150 \mathrm{t} \cdot \mathrm{ha}^{-1}$ of compost or 400 to $500 \mathrm{t} \cdot \mathrm{ha}^{-1}$ of green manure is recommended before planting (Lu, 1992). Wolf and Wegert (1993) noted that precise fertilizer recommendations should be determined by soil sampling and analysis.

Fig. 2. The distribution of sea buckthorn in Europe and Asia.

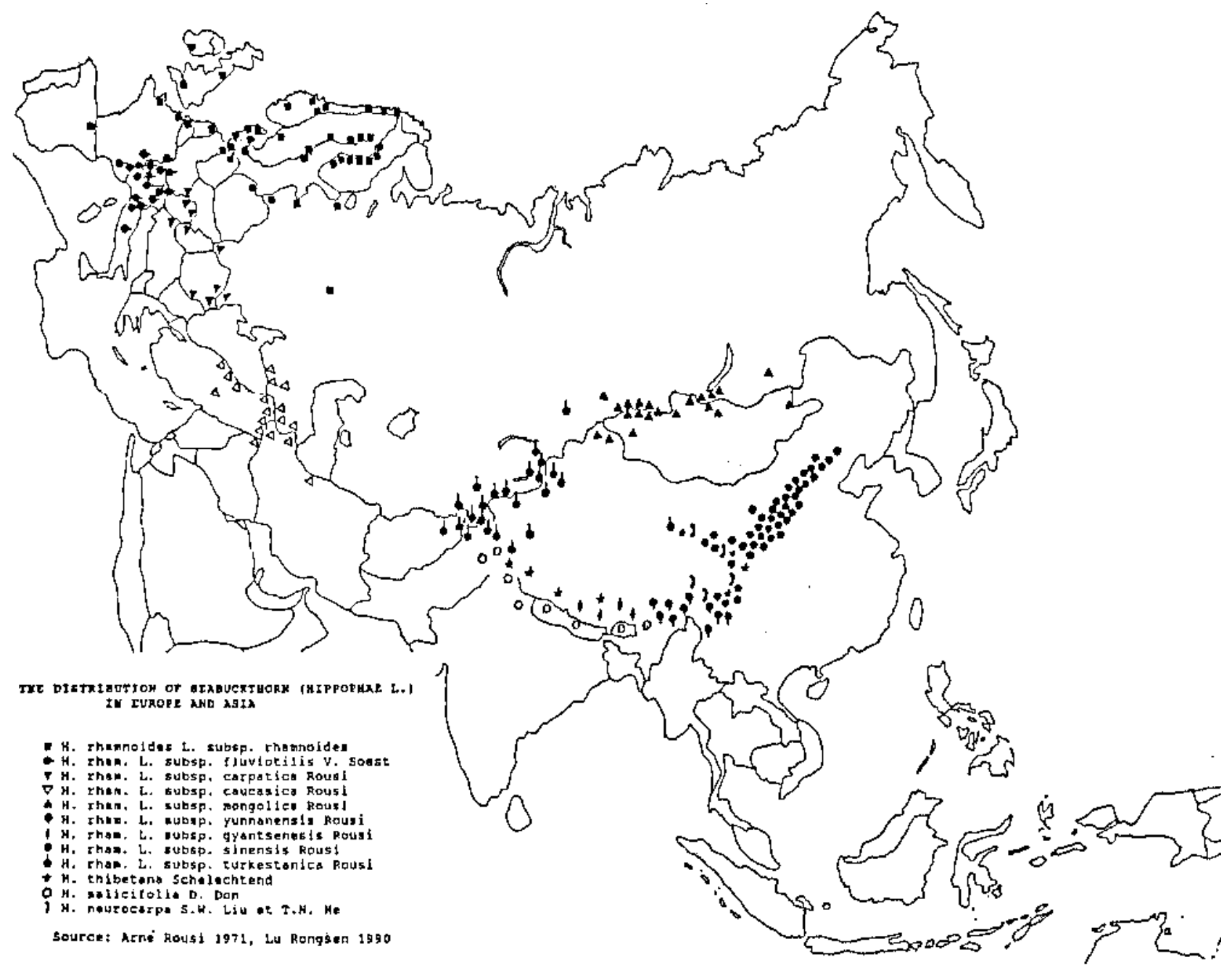


Temperature. Seabuckthorn can endure the extreme minimum air temperature of $-43^{\circ} \mathrm{C}$ without sustaining long-term damage ( $L u, 1992)$. Conversely, it can survive summer temperatures up to $40{ }^{\circ} \mathrm{C}$, although $\mathrm{Lu}$ (1992) reported that temperatures above $30^{\circ} \mathrm{C}$ burned leaves on newly planted seedlings. The latter observation may be the reason why efforts to introduce sea buckthorn from mountain areas to the plains of Asia often have failed.

Spacing. The largest sea buckthorn population in $\mathrm{N}$ orth America is in the $C$ anadian prairies, where about $1000 \mathrm{~km}$ offield shelterbeltsareplanted annually (Schroeder and Yao, 1995). T wo-year-old seedlingsare planted for shelterbelts normally in one to three rows, 1 to $2 \mathrm{~m}$ apart within rows and 5 $\mathrm{m}$ between rows. Wolf and Wegert (1993) recommended aspacing of $1 \mathrm{~m}$ within therow and 4 to $4.5 \mathrm{~m}$ between rows to allow equipment access, with rows oriented in a north-south direction to provide maximum light. Beldean and Leahu (1985) reported that fruit yields are greatly influenced by exposure to sunlight, as sea buckthorn will not tolerate shade. $\mathrm{H}$ igh density orchards $(1 \times 1 \mathrm{~m})$ are being considered in Europeto facilitate overthe-row harvesting equipment (O lander, 1995).

Pruning. The purpose of pruning sea buckthorn is to train branches, promote growth, and facilitate harvesting (Albrecht et al., 1984). Savkin and M ukhamadiev (1983) reported that moderate pruning will increase the yield and fruiting life of the plants. Sea buckthorn grows up to 2 to $3 \mathrm{~m}$ in 4 years and forms its crown at the base of the main trunk. The crown should be pruned annually to remove overlapping branches, and long branches should be headed to encourage development of lateral shoots. In about the fifth year, the main trunk stops growing, and branches begin to grow from lateral buds. Mature, fruiting plants should be pruned to allow more light penetration if the bush is dense. To prevent sea buckthorn from premature senescence, 3-year-old branches should bepruned for rejuvenation ( $L u$, 1992). In Russia, pruning trials were carried out with sea buckthorn with the goal of creating a hedge to allow efficient mechanical harvesting (Savkin and Mukhamadiev, 1983). Similar work is underway in G ermany ( $G$ aetke and Triquart, 1992) and Sweden (S. Olander, personal communication).

Weed control. Weed control or vegetation management is very important in seabuckthorn plantings. Proper weed control promotes growth of newly planted seedlings. Cultivation in new plantings should not disturb the soil 8 to $10 \mathrm{~cm}$ below the surfaceso that shallow roots are not damaged (Gonchar and Saban, 1986). H erbicides for sea buckthorn plantations currently are being evaluated by the PFRA Shelterbelt Centre. Several chemicals are registered in Canada for weed control in sea buckthorn shelterbelts (Schroeder and Alspach, 1995). Albrecht et al. (1984) cautioned that only low concentrations of herbicides should be used. Low rates of simazineand lenacil applied to cuttings of sea buckthorn 10 days after planting and again 2 months later gave effective weed control and increased survival rate and growth (Shlyapnikova, 1985).

Male : female plant Ratio in the planting. For economical reasons, the ratio of male to female plants is important, as the number of fruitbearing trees should be maximized. In Canada, sea buckthorn plants for shelterbeltsaregrown from seeds. Consequently, seedlings of unknown sex are planted, which resultsin an uneven distribution of male and female plants within each planting. This practice has long-term effects on total yield. To avoid this problem, the easiest approach would be vegetative propagation from promising mature plants of known sex. Recommendationsformale : female ratio vary. Gakov (1980) considered that $6 \%$ to $7 \%$ male trees is adequate for pollination, whereas Albrecht et al. (1984) and Wolf and Wegert (1993) recommended 8\% to $12 \%$ The Siberian Institute of $\mathrm{H}$ orticulture in Russia recommended one male : female mixed row for every two rows of female plants. In the mixed row, every fifth plant is a male. Goncharov (1995) reported that this design gave significantly higher fruit yields compared to other designs. For effective pollination, the male variety should be cold resistant and have a long flowering period, an adequate amount of pollen, long-lived, and good vigor (Garanovich, 1995), since a pollinator had an appreciable effect on fruit weight, flavor, and ripening (Buglova, 1981).

Harvesting. Berries persist on the branchesall winter, perhapsdueto the absence of an abscission layer. This resultsin an attractiveo rnamental plant in winter, but it is undesirable for harvesting. In Saskatchewan, C anada, the total labor cost for harvesting an orchard of 4 ha was estimated to be $58 \%$ of the total cumulative production cost over 10 years. In Asia, harvesting is still done by hand or with picking tools. This difficult and laborintensive process requires about 1500 $\mathrm{h} \cdot \mathrm{ha}^{-1}$ (G aetke and Triquart, 1993). Wolf and Wegert (1993) and O lander (1995) reported that difficulties associated with harvesting are major barriers to orchard production of sea buckthorn in E urope. Therefore, one of the most important factors for the success of sea buckthorn as a viable cash crop is a better and more economical harvesting method.

Koch (1981) harvested entire fruiting shoots with pneumatic shears. Botenkov and Kuchukov (1984) developed a device for hand-picking that consists of two hinged jaws with teeth and brushes. The development of mechanical harvesting techniques for sea buckthorn has attracted considerable attention. Savkin and M ukhamadiev (1983) designed apruning machine to trim sea buckthorn into a hedge suitable for mechanical harvesting. M echanical harvesters have been developed in Sweden, Germany, and Russia (Olander, 1995). H owever, most have disadvantages, such as fruit and bark damage and low efficiency. $\mathrm{H}$ arvesting equipment tested include shakers (Affeldt et al., 1988; $G$ aetke et al., 1991), vacuum suction (Varlamov and Gabuniya, 1990), and quick freezing ( $G$ aetke and Triquart, 1993). M any harvesters are based on the principle of cutting off fruit-bearing branches ( $G$ aetke and Triquart, 1992; O lander, 1995). O lander (1995) reported development of an over-therow mechanical harvester that removes fruit-laden branches and extracts the fruit by shaking the branches in an axial direction.

In Germany, considerable work on mechanical harvesting of sea buckthorn has been completed. Wolf and Wegert (1993) reported techniques in which fruiting branches were removed and frozen overnight at $-36^{\circ} \mathrm{C}$. Frozen fruit were removed by beating the branches. This method provided berries with excellent quality, but it was labor intensive (about $450 \mathrm{~h} \cdot \mathrm{ha}^{-1}$ ). 
Fig 3. Possible uses for components in different sea buckthorn plant parts.
Gaetke and Triquart (1993) developed a harvester that works on the riddleprinciple. I $\mathrm{n}$ thissystem, pruned branches are hand fed into the harvester, and the fruit is separated from branches and leaves by screen conveyors and fans.
The use of hormone treatments to facilitate fruit release is promising. Trushechkin et al., (1973) reported that Ethrel (ethephon) at $2000 \mathrm{mg} \cdot \mathrm{L}^{-1}$ of water decreased fruit detachment force by $30 \%$ D emenko et al. (1986a) suggested that the inability of ripe fruit to

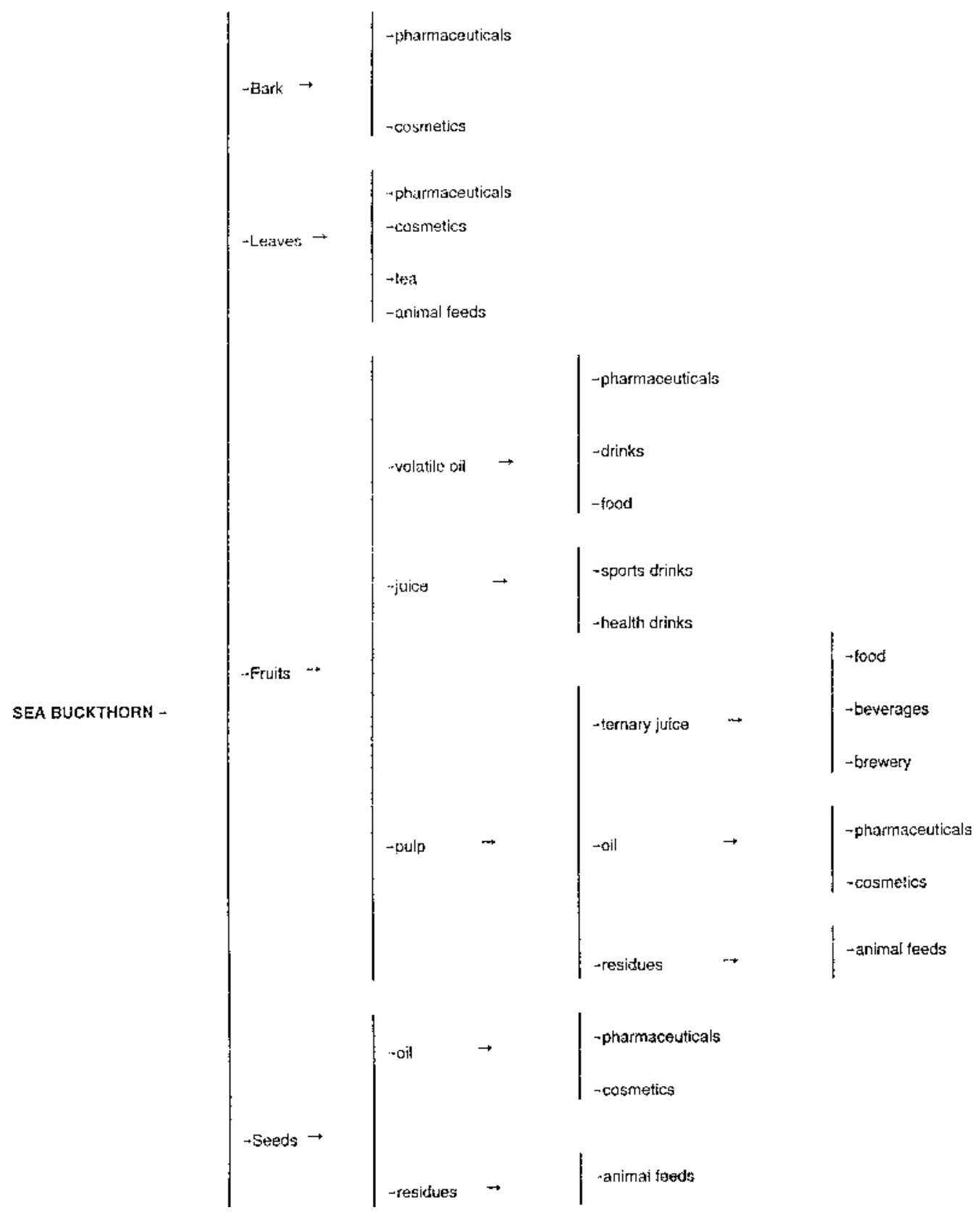


abscise iscau sed by compartmentation of internal ethylene in seeds. Ethylene treatment induced the formation of an abscission layer, which could make harvesting more efficient ( $D$ emenko et al., 1986b; D emenko and Korzinnikov, 1990).

Yield. Like any other crop, yield of sea buckthorn is affected by various factors such as genotype, soil conditions, annual precipitation, temperature, crop management, numbers of fruit-bearing branches, and time and methods of harvesting (Kondrashov, 1981). Yield data of sea buckthorn are scarce, since most fruit collection is from natural habitats, plantations for controlling soil and water erosion, and field shelterbelts. Wolf and Wegert (1993) reported yield of $5 \mathrm{t} \cdot \mathrm{ha}^{-1}$ from an orchard plantation in Germany. T otal yields reported in the literature from various regions were mostly estimates from experimental plots, cultivated under ideal conditionsand management (I.M. Garanovich, personal communication). In Saskatchewan, Canada, fruit production in shelterbelts ranges from good to excellent, some selected plants producing 5 to $7 \mathrm{~kg}$ annually. This equates to yields of 4 to $5 \mathrm{t} \cdot \mathrm{ha}^{-1}$. Canada Sea Buckthorn Ltd. (British Columbia) estimated an average of $3.25 \mathrm{~kg} /$ tree (6-year-old) collected from shelterbelt plantings (C. M CL oughlin,, personal communication). O rchardswith 4000 trees/ ha and a 1:6 male and female ratio should yield about $11 \mathrm{t} \cdot \mathrm{ha}^{-1}$. $D$ etailed study is underway in Canada on the effects of crop management on yield.

\section{Breeding and selection}

There is a wide range of morphological diversity among sea buckthorn seedlings and mature plants within each subspecies, which is a good indication that there are excellent opportunities for plant improvement by breeding or selection for desired characteristics. Phenological observations have shown a clear gradient of growth rhythm and plant size corresponding to geographical distribution ( $Y$ ao and Tigerstedt, 1994), which indicatesthat selection based on responses of plants to a specific growing region is important. This selection procedure is important in any country beforeseabuckthorn can be developed into a new viable crop.

B reeding sea buckthorn has been conducted for decades in Russia (Goncharov, 1995), U kraine (Gladon et al., 1994), China (H uang, 1995), and Finland (H irrsalmi, 1993). The first breeding programs began with mass selection from natural populations. This method is still common practice (Wahlberg and Jeppsson, 1990) but is gradually being replaced by hybridization (H uang, 1995; Yao and Tigerstedt, 1994). Polyploid breeding was reported in R ussia where autotetraploidswereinduced bycolchicine (Shchapov and Kreimer, 1988). There have been no reports of genetic engineering in sea buckthorn breeding.

Breeding programs exist in Sweden (Wahlberg and Jeppsson, 1990, 1992), Finland (H irrsalmi, 1993; Yao and Tigerstedt, 1994), and Germany (Albrecht, 1993; M uller, 1993). Finnish and Swedish programs have concentrated on mass selection and hybridization. I $\mathrm{G}$ ermany, the objective was to establish a collection of sea buckthorn representing the genetic spectrum of thespecies(M uller, 1993). A sea buckthorn breeding program has been initiated recently in Canada (Schroeder, 1995). I t includes a longterm breeding population made up of progeny from diverse foreign wild collections and a short-term breeding population of superior individual plants selected from local plantations.

I mportant characters that need improvement in seabuckthorn areyield (Kondrashov, 1986a; H uang, 1995), fruit size (Buglova, 1978), winter hardiness (Kalinina, 1987), thornlessness (H irrsalmi, 1993; Albrecht, 1993), fruit quality and early maturity (Yao and Tigerstedt, 1994), growth habit and long pedicel for mechanical harvest (Wahlberg and J eppsson, 1990), and nitrogen-fixing ability ( $\mathrm{H}$ uang, 1995). Kondrashov (1986a, 1986b) reported that average fruit weight and number of flower buds per unit length of branch are the most reliable traits for yield selection in the Altai region of Siberia. P.L. G oncharov of R ussia (personal communication) pointed out that thornlessness could be selected in young seedlings; however, yield of each breeding line cannot be determined until at least the fourth year. Fruit size, thorniness, and hardiness reportedly are controlled by quantitative genes, and selection for one of these characters will not adversely affect others (H uang, 1995).

\section{Propagation}

The most common methods for propagating seabuckthorn arebyseed, softwood or hardwood cuttings, and layering and suckers. M icropropagation using meristem culture has been investigated (Burdasov and Sviridenko, 1988; M ontpetit and Lalonde, 1988) but is not commonly used.

Seeds. Propagation from seed is relatively simple and produces a large number of seedlings at fairly low cost compared with other propagation methods. Storage affectsseed viability. Smirnova and Tikhomirova (1980) reported that seeds of $\mathrm{H}$ ippophae rhamnoi deslost $60 \%$ of viability after 4 to 5 years of storage.

Internal seed dormancy can be broken by stratification in moist sand for $90 \mathrm{~d}$ at $5{ }^{\circ} \mathrm{C}$ (Siabaugh, 1974). Seed sof sea buckthorn need high temperature to germinate. At 10 to $12{ }^{\circ} \mathrm{C}$, Lu (1992) reported $13.2 \%$ germination after $47 \mathrm{~d}$ compared to $95 \%$ in $6 \mathrm{~d}$ for seeds at 24 to $26{ }^{\circ} \mathrm{C}$. Vernik and Z hapakova (1986) also reported more rapid germination at 25 to $27^{\circ} \mathrm{C}$ than at $20^{\circ} \mathrm{C}$. Good results also can be obtained by soaking seeds in hot water $\left(70{ }^{\circ} \mathrm{C}\right.$ ) for 24 to $48 \mathrm{~h}$, stirring frequently, then letting the water cool to room temperature (Lu, 1992). After soaking, seeds should be air dried before sowing. This technique is useful when sowing outdoors in spring or indoorsin a greenhouse. At the PFRA Shelterbelt Centre, Saskatchewan, nonstratified seeds sown in late September at a depth of $1 \mathrm{~cm}$ and a rate of 100 seeds/ $\mathrm{m}$ in rows $60 \mathrm{~cm}$ apart emerged the following spring with a 90\% germination rate.

Cutrings. Cuttings produce rooted plants with the same genotype as the parent plant. The cuttings will bear fruit 1 to 2 years earlier than seedpropagated trees. Sea buckthorn can be propagated using either hardwood or softwood cuttings.

Hardwood cutrings. The percentage of successful rooting from hardwood cuttings varies. Avdeev (1984) reported $86 \%$ to $100 \%$ success. G aranovich (1984) reported that, in the greenhouse under artificial mist, rooting success was $20 \%$ lower with hardwood cuttingsthan with softwood cuttings, but plants from hardwood cuttings attained heights of $90 \mathrm{~cm}$ by the end of the first growing season and could be planted out the next spring, 
whereas plants from softwood cuttings needed 1 to 2 years before transplanting to the field. Kondrashov and Kuimov (1987) reported that hardwood cuttings with apices removed were rooted successfully outdoorsunder plastic in pure sand or a sand and peat (1:1) mixture. In a separate experiment, they showed that 2-year-old wood, cut beforebudbreak and stored for $10 \mathrm{~d}$ in sawdust at 10 to $15^{\circ} \mathrm{C}$, gave $100 \%$ rooting in the field. Kuznetsov (1985) recommended taking cuttings before bud break, soaking in water (18 to $20^{\circ} \mathrm{C}$ ) for 7 days, and planting in thefield with dark polyethylenemulch. In British Columbia, we obtained $90 \%$ rooting of cuttingstaken in mid-M arch, stored in plastic bags at $0^{\circ} \mathrm{C}$ until $\mathrm{M}$ ay, and placed in pots filled with peat in a heated propagation box (18 to $22^{\circ} \mathrm{C}$ ) indoors under fluorescent light. Lu (1992) reported that hardwood cuttings have not been used widely in nurseries.

Softwood cutrings. A vdeev (1976) reported that softwood cuttings collected from an 8-year-old tree in early spring, treated with IBA (50 $\left.\mathrm{mg} \cdot \mathrm{L}^{-1}\right)$ solution and planted in a peat and sand (2:1) mixture under mist, had $96 \%$ to $100 \%$ rooting in 9 to $11 \mathrm{~d}$. Balabushka (1990) compared the effects of IAA, IBA, and chlorophenoxyacetic acid on rooting of sea buckthorn and found that IAA root dips were superior to the other hormone treatments. I vanicka (1988) reported that, with or without I BA $(0.1 \%$ to $0.3 \%$ ) treatment, semi-lignified $\mathrm{H}$ ippophaerhamnoi descuttingsrooted readily in a peat, polystyrene granules and sand (1-2:1:0.5) mixture under mist in a plastic house. Timing of cutting collection is important. Kniga (1989) reported that, in the Kiev region of U kraine, the optimum time waslate M ay. Kondrashov and Kuimov (1987) reported that cuttingstaken in late] unefrom severely pruned branches (pruning wasconducted in early spring before budbreak) successfully rooted (95\%to 98\%) in the greenhouse under mist.

LAYering AND suckers. Root cuttingsalso can be an effective propagation method for sea buckthorn ( $A$. Bruvlis of Latvia, personal communication). R oot cuttings were planted in pots and placed in a greenhouse for 6 weeks beforebeing transplanted to the field at a spacing of $8 \times 20 \mathrm{~cm}$. Cuttings need to be acclimated to field conditions before planting by placing pots in a shady area for 1 week. The best results were obtained in sandy loam at $\mathrm{pH} 6$ to 6.5 with medium humus content. Sea buckthorn easily produces suckers within a few years of planting, which is a good source for propagation (Kondrashovand Kuimov, 1987). The possibility of invasiveness by suckers to surrounding areasishigh; routing cultivation and herbicide application are the best control measures for this potential weediness characteristics of sea buckthorn.

\section{Multipurpose use}

Environmental value. Thewide adaptation, fast growth, strong coppicing, and suckering habits, coupled with efficient nitrogen fixation, make sea buckthorn particularly suitable for planting in degraded soils. In China, seabuckthorn has controlled soil erosion and water loss effectively and increased land reclamation. In addition, the harvest of sea buckthorn fruit has provided value-added industries to support the economy of rural regions of Asian countries. I n Canada, sea buckthorn has proved highly beneficial for enhancement of wildlifehabitat, farmstead shelterbelts, erosion control, and mineland reclamation.

Chemical components. Sea buckthorn fruit is rich in carbohydrates, protein, organic acids, amino acids, and vitamins (Bernath and Foldesi, 1992). Fruit contain 16 to 28 mg carotenoids/ $100 \mathrm{~g}$ fruit, which can be used as food additives (Kudritskaya et al., 1989). Flavonoid content in leaves and fruit ranges from 310 to $2100 \mathrm{mg} / 100 \mathrm{~g}$ air-dried leaf and 120 to $1000 \mathrm{mg} / 100 \mathrm{~g}$ fresh fruit, respectively ( $C$ hen et al., 1991; Glazunova et al., 1984, 1985). Total volatile oil from the fruit is $36 \mathrm{mg} \cdot \mathrm{kg}^{-1}$ (H irvi and Honkanen, 1984), dry matter is $24.6 \%$ to $33.8 \%$ (I goshina et al., 1987), and essential oil extracted from seeds ranged from $8 \%$ to $12 \%$ (w/ w) (Lu, 1992).

Bounous and Zanini (1988) found that fruit maturity affects $\mathrm{N}, \mathrm{Ca}$, $\mathrm{K}, \mathrm{N}$ a, M g, Cu, Fe, Zn, M n, titratable acidity, pH, moisture, glucose, fructose, and ascorbic acid content. $\mathrm{H}$ arju and Ronkainen (1984) reported that the trace elements found in liqueurs prepared from seabuckthorn included $\mathrm{Al}, \mathrm{As}, \mathrm{Ca}, \mathrm{Cd}, \mathrm{Cr}, \mathrm{Cu}, \mathrm{Fe}, \mathrm{K}, \mathrm{Mg}, \mathrm{M} \mathrm{n}$, $\mathrm{Na}, \mathrm{Ni}, \mathrm{Pb}, \mathrm{Rb}$, and $\mathrm{Zn}$. D ifferencesin chemical composition, carbohydrates, moisture, lipids, acids, and vitamins $A$ and $C$ werefound among thelarge and small fruit (Chen et al., 1991) and among subspecies ( $L u, 1993$ ) and geographic locations (Wang, 1990). Eliseev (1976) indicated that thelevels of the biologically active substances such as ascorbic acid and carotene were higher in tree-like forms than in bush forms. Frankeand M uller (1983) analyzed the fat of fruit and seeds and found $47 \%, 21 \%$ saturated fatty acids and $53 \%, 39 \%$ unsaturated fatty acids respectively.

Nutritional values. The value of sea buckthorn is often based on the nutritional value of itsfruit ( $M$ agherini, 1986). Sea buckthorn berries are among the most nutritious and vitamin-rich fruit known. The fruit, including seeds, contain a large amount of essential oils and vitamin C (Centenaro et al., 1977; Novruzov and Aslanov, 1983). The vitamin C concentration in berriesvaries depending on species, geographical location, and physiological maturity (Bernath and foldesi, 1992; Zhou et al., 1991) from $360 \mathrm{mg} / 100 \mathrm{~g}$ of berries for the European subspecies rhamnoides (Rousi and Aulin, 1977; Yao et al., 1992) to $2500 \mathrm{mg} / 100 \mathrm{~g}$ of berries for the $C$ hinesesubspeciessinensis(Yao and Tiherstedt, 1994), which ishigher than strawberries (205 mg vs. 64 mg/ $100 \mathrm{~g}$; Gontea and Barduta, 1974), kiwi fruit ( 300 to $1800 \mathrm{mg}$ vs. 100 to $470 \mathrm{mg} / 100 \mathrm{~g}$ ), orange ( $50 \mathrm{mg} / 100$ $\mathrm{g})$, and tomato (12 mg/ $100 \mathrm{~g})$ ( $\mathrm{Lu}$, 1992). Sea buckthorn is also high in protein, especially globulins and albumins(Solonenko and Shishkina, 1983), carotene (Kostyrko, 1990), fatty acids (L oskutovaet al., 1989), and vitamin E (Bernath and Foldesi, 1992). Fatty acids and vitamin $\mathrm{E}$ content are higher than in wheat, safflower, maize, or soybean ( $L$ u, 1992). The leaves of sea buckthorn contain many nutrientsand bioactive substances, such as urtica dioica, vaccinium myrtilis, and berberis vulgaris, which are suitable for animal feed (M orar et al., 1990).

Medicinal value. M edicinal uses of sea buckthorn are well documented in Asia and E urope. C linical investigations on medicinal uses were initiated in R ussia during the 1950s (G urevich, 1956). Sea buckthorn oil is approved for clinical use in hospitals in Russia and in China, where it was formally listed in the Pharmacopoeia in 1977 (Xu, 1994). More than 10 different 
drugs have been developed from sea buckthorn in these countries and are available in different forms (e.g., liquids, powders, plasters, films, pastes, pills, liniments, suppositories, aerosols, etc.) and can be used for treating oral mucositis, rectum mucositis, vaginal mucositis, cervical erosion, radiation damage, burns, scalds, duodenal ulcers, gastric ulcers, chilblains, skin ulcers caused by malnutrition, and other skin damage (Abartene and M alakhovskis, 1975; Buhatel et al., 1991; C hen, 1991; C heng et al., 1990; D ai et al., 1987; Kukenovet al., 1982). The most important pharmacological functions of sea buckthorn oil can be summarized as diminishing inflammation, disinfecting bacteria, relieving pain, and promoting regeneration of tissues. It also can be used for skin grafting, cosmetology, and treatment of corneal wounds. I $\mathrm{n}$ an unconfirmed report from China, 350 patientstreated with beauty cream mad efrom sea buckthorn oil had positive therapeutic effects on xanthopsis, melanosis, senile skin wrinkles, and freckles (Zhong et al., 1989). Russian research reported that 5-hydroxytryptamine(hippophan) isolated from sea buckthorn bark inhibited tumor growth (Sokoloff et al., 1961). M ore recently, studies on the anti-tumor effects of sea buckthorn oil have shown positive results in China (Zhong et al., 1989).

\section{Conclusion}

Sea buckthorn is a unique and valuable plant species currently being domesticated in various parts of the world. The species has been used to a limited extent in North America for conservation plantings, but the use of food and nonfood seabuckthorn products has not been pursued. The plants are easily propagated and yields are relatively high, and production is reliable, with the potential market mainly in Europe. The main constraint to large-scale fruit production in $\mathrm{N}$ orth A merica is harvesting. This problem is being addressed through breeding programs and equipment development. M ost sea buckthorn research has been conducted in Asia and Europe, specifically China, Russia, and Germany. Recently interest in western Europe and $\mathrm{C}$ anada has increased, and active research programs are underway.

U nique plant products, especially those with proven nutritional quality, are gaining popularity in North
America. Development of a N orth A merican sea buckthorn industry presentsa unique opportunity for agricultural production of a value-added crop on marginal land.

\section{Literature Cited}

A bartene, D.Y. and A.I. Malakhovskis. 1975. Combined action of a cytostatic preparation and sea buckthorn oil on biochemical indices. part 2 hisphen. Lietuvos TSR M okslu Akademijos Darbai Serija C Biologijos M okslai 1:167-171.

A ffeldt, H.A., D.E. Marshall, and G.K. Brown. 1987. Relative dynamic displacements within a trunk shaker clamp. Trans. ASAE 31:331-336.

A kkermans, A .D .L., W . R oel ofsen, J . B lom, K. H u ssdanell, and R . H arkink. 1983. U tilization of carbon and nitrogen compounds by Frankia in synthetic media and in root nodules of Alnus glutinosa, $\mathrm{H}$ ippophae rhamnoides, and Datisca cannabina. Can. J. Bot. 61:2793-2800.

A lbrecht, H .J. 1993. N ew demands faced by buckthorn breeding, p. 57-60. In: Cultivation and utilization of wildfruit crops. Bernhard Thalacker Verlag G mbh \& Co. (in German).

A lbrecht, H.J., J. Gerber, H.J. K och, and D. Wolf. 1984. Experience in growing sea buckthorn. Gartenbau 31:242-244. (H ort. Abstr. 54:9033).

A ndreeva, I.N., E.E. Fedorova, V.B. Il'yasova, and A.A. Tibilov. 1982. U Itrastructure of nitrogen-fixing and wintering nodules in one-year seedlings of sea buckthorn and oleaster $\mathrm{H}$ ippophaerhamnoides, Elaeagnus argentea. Soviet Plant Physiol. (U SA) 29:109-116.

A vdeev, V.I. 1976. Propagation of H ippophae rhamnoides by softwood cuttings under mist. Kratkie Tezisy Dokl 2-i Vses. Konf. Molodykh U chenykh po Sadovodstvu (1976) 72-74. (H ort. Abstr. 48:318).

A vdeev, V.I. 1984. Propagation of fruit crops by cuttings in upper Tadjikistan. Intensivnye Sposoby Vyrashchivaniya Posadochnogo M ateriala Sadovykh Kultur (1984):51-56. (H ort. Abstr. 55:40).

Bailey, L.H . and E.Z. Bailey. 1978. H ortus Third, A concise dictionary of plants cultivated in the U nited States and Canada. $\mathrm{M}$ acM illan Pub. Co.

Balabushka, V.K . 1990. Results of the trials of growth regulators on summer cuttings of introduced woody plants. Byulleten Glavnogo Botanicheskogo Sada 156:6567. (H ort. Abstr. 61:5083).

Balint, K ., A. Terpo, and L. Zsoldos. 1989.
Sea buckthorn as suitable plant for reclamation of red mud impoundmentsin $\mathrm{H}$ ungary, p. 268-274. In: Proc. Intl. Symp. Sea Buckthorn (H .rhamnoidesL.). Xian, China. TheSecretariat of Intl. Symp. on Sea Buckthorn. $O$ ct. 1989.

Beldean, E.C. and I. Leahu. 1985. $\mathrm{H}$ ippophaerhamnoides-A valuable berryproducing pioneer species. Forstarchiv 56:249-253.

Bernath, J . and D. Foldesi. 1992. Sea buckthorn (H ippophaerhamnoidesL.): A promising new medicinal and food crop.). H erbs, Spices M edicinal Plants 1:27-35.

Biswas, M.R. and A.K. Biswas. 1980. In desertification, control the desertsand create pastures. Environ. Sci. Applications 12:145-162.

Bond, G. 1983. T axonomy and distribution of non-legume nitrogen-fixing systems, $p$. 55-87. I n: J.C. Gordon and C.I. Wheeler (eds.). Biological nitrogen fixation in forest ecosystems: Foundations and applications. M artinus N ijhoff, D r. W. Junk Publishers, The $\mathrm{H}$ ague.

Boten kov, V.P. and N .M. K uchukov. 1984. D evice for collecting fruits of $\mathrm{H}$ ippophae rhamnoi des L esnoeK hozyaistvo 2:46-47.

Bounous, G. and E. Zanini. 1988. The variability of some components and biometric characteristics of the fruits of six tree and shrub species, p. 189-197. In: Lampone, mirtillo ed altri piccoli frutti Atti, convegno, trento, 1987. Rome, M inistero agricoltura e foreste, 1988. (H ort. Abstr. 60:4153).

Buglova, T.L. 1978. Fruit size in some ecological and geographical groupsof $\mathrm{H}$ ippophae rhamnoides and the inheritance of large-fruitedness in the hybrid progeny. N uach. tr. O msk. s.-kh. in-t 175:26-29. (Plant Breeding Abstr. 50:4357).

Buglova, T.L. 1981. Effect of male plants of $\mathrm{H}$ ippophae rhamnoides on the yield of a plantation. LesnoeK hozyaistvo 11:39-40.

Buhatel, T., S. Vesa, and R. M orar. 1991. $D$ ata on the action of sea buckthorn oil extract in the cicatrization of wounds in animals. Buletinul Institutului Agronomic Cluj-N apoca Seria Z ootehnie si M edicina Veterinara 45:129-133.

Burdasov, V.M. and E.I. Sviridenko. 1988. Production of regenerates of sea buckthorn from apical meristems in in-vitro culture. Sibirskii Vestnik Sel'skokhozyaistvennoi N auki 3:106-110.

Centenaro, G., G.P. Capietti, F. Pizzocaro, and $A . M$ archesini. 1977. The fruit of the sea buckthorn $\mathrm{H}$ ippophae rhamnoi des as a source of vitamin C. Atti della Societa I taliana di scienze $\mathrm{N}$ aturali del M useo civico di storiaN aturaledi M ilano 118:371-378. 
Chen, J.H. 1991. Effect of the immunomodulating agents (BCG) and the juice of $H R L$ on the activity of splenic N K cells and LAK cells from tumour bearing mice. Chinese J. M icrobiol. and I mmunol. 11:105-108.

Chen, T.G., M.K. N i, R . Li, F. Ji, T. Chen, M.K. N i, R. Li , and F. Ji. 1991. Investigation of the biological properties of $C$ entral Asian Sea Buckthorn growing in the province of Kansu, China. Chemistry of $\mathrm{N}$ atural Compounds 27:119-121.

Cheng, T., T. Li, Z. Duan, Z. Cao, Z. Ma, and $P$. Zhang. 1990. Acute toxicity of flesh oil of $\mathrm{H}$ ippophae rhamnoides $\mathrm{L}$. and its protection against experimental hepatic injury. Chung Kuo Chung Yao Tsa Chih 15:45-47.

Cireasa, V. 1986. H ippophae rhamnoides $\mathrm{L}$. extension on Rufeni H ill, I asi district. Lucrari Stiintifice, Institutul Agronomic "I on Ionescu de la Brad", H orticultura 30:75-77. (H ort. Abstr. 58:6535).

Dai, Y.R., C.M. Gao, Q.L. Tian, and Y. $Y$ in. 1987. Effect of extracts of some medicinal plants on superoxide dismutase activity in mice. Planta M edica 53:309-310.

D avidson, C.D., R.J. Enns, and S. Gobin. 1994. L andscapeplants at M orden Arboretum. Agriculture \& Agri-Food Canada, M orden, M anitoba, Canada.

Degtyar eva, I.I., E.T. Toteva, E.V. Litinskaya, A.V. Matvienko, N.H. Y urzhenko, L.N . Leonov, E.V. K homenko, and V.P. N evstruev. 1991. Lipid peroxidation level and vitamin $\mathrm{E}$ concentrations in the treatments of ulcer patients. Klinicheskaya M editsina 69:38-42.

Demenko, V.I . and Y.S. K orzinnikov. 1990. Effect of surface-activity compounds and copper ions on ethylene producers inducing fruit abscission in the sea buckthorn. Fiziologiya Rastenii 37:596-601.

Demenko, V.I., M.B. Levinsky, and O.D. Mikityuk. 1986a. Abscisic acid, ethylene, growth and abscission of sea buckthorn fruits (H ippophae rhamnoides L.). Acta H ort. 179:639-644.

Demenko, V.I., O.D. Mikityuk, and M.B. Levinskii. 1986. Abscisic acid, ethylene, growth and fruit drop in sea buckthorn. Fiziologiya Rastenii 33:188-194. (H ort. Abstr. 56:7655).

D obritsa, S.V . and S.N . N ovik. 1992. Feedback regulation of nodule formation in $\mathrm{H}$ ippophae rhamnoides Plant and Soil 144:45-50.

Egyed-Balint, K . and A. Terpo. 1983. Effect of red mud on growth and element accumulation in some plant species. Kerteszeti E gyetem Kozlemenyei 47:127136.
Eliseev, I.P. 1976. Biologically active substances in the fruits of $\mathrm{H}$ ippophae rhamnoides in Central Asia and the Caucasus. Biol. aktiv. veshchestva plodov $\mathrm{i}$ yagod. (1976) 161-163. (Plant Breeding Abstr. 48:5917).

Eliseev, I.P. and V.A. Fefelov. 1977. M aterial for studying $\mathrm{H}$ ippophae rhamnoidesin Kabardino-Balkaria. T rudy G or?kovskogo Selskokhozyaistvennogo Instituta 105:37.

Franke, W. and H. Muller. 1983. A contribution to the biology of useful plants. 2 . $Q$ uantity and composition of fatty acids in the fat of the fruit flesh and seed of sea buckthorn. Angewandte Botanik 57:7783.

Gaetke, R . and E.Triquart. 1992. Pruning machine for mechanized harvest of sea buckthorn. Gartenbau M agazin 1:57-58.

Gaetke, R. and E. Triquart. 1993. First results with an improved sea buckthorn harvesting technology, p. 37-41. In: Cultivation and utilization of wild fruit crops. Bernhard Thalacker Verlag Gmbh \& Co. (in German).

Gaetke, R., G.K lein, and D. W olf. 1990. Composition of sea buckthorn and its development during maturation. Erwerbsobstbau 32:224-226.

Gaetke, R ., M. Schmidt, E. Triquart, and F. Wegert. 1991. Ernteverfahren sanddorn. Erwerbsobstbau 2:49-51.

Gakov, M .A . 1980. Prospects for the development of $\mathrm{H}$ ippophae rhamnoides in the Tuva, USSR. Lesnoe Khozyaistvo 2:5152.

Garanovich, I.M. 1984. Features of the vegetative propagation of $\mathrm{H}$ ippophae rhamnoi desfor introduction in Belorussia. Lesnoe Khozyaistvo 2:27-29.

Garanovich, I.M. 1995. Introduction and selection of $\mathrm{H}$ ippophaein B elarus. I n: Proc. Intl. Sea Buckthorn. Dec., 1995. Beijing, China.

Gladon, R.J., D.J. H annapel and M.V. Kolomiets 1994. Small-fruit and tree-fruit research centres in $\mathrm{U}$ kraine. $\mathrm{H}$ ortScience 29:1214, 1393-1395.

Glazunova, E.M., N .D.Gachechiladze, V.V. Bondar, Y.S. K orzinnikov, I.M. Potapova, and A.F. Gur'yanov. 1984. Biochemical fruit characteisitics of $\mathrm{H}$ ippophae rhamnoides $L$. growing in the Western Pamirs. Rastitel'nye R esursy 20:232-235. (H ort. Abstr. 54:6135).

Glazunova, E.M., N .D. Gachechiladze, V.I . Litvinenko, and T.P. Popova. 1985. Flavonoidsin leavesof sea buckthorn growing in the Western Pamir mountains. Fiziologiya i Biokhimiya Kul'turnykh Rastenii (1985) 107-109. (Hort. Abstr.
$57: 3263)$.

Gonchar, M.T. and B.A. Saban. 1986. Choice of tree and shrub species for afforestation of sites after opencast mining of sulphur. Lesnoe Khozyaistvo 9:47-49.

Goncharov, P.L. 1995. Sea Buckthorn in Siberia: Problems and solutions. In: Proc. Intl. Sea Buckthorn Workshop, Beijing, China. Dec., 1995.

Gontea, I. and Z. Barduta. 1974. The nutrient value of fruits from $\mathrm{H}$ ippophae rhamnoi des. I giena 23:13-20. (N utr. Abstr. and Rev. 45:8559).

Gurevich, S.K . 1956. The application of sea buckthorn oil on ophthamology. Vesttn. O ttamologu 2:30-33.

$\mathrm{H}$ arju, $\mathrm{K}$. and $\mathrm{P} . \mathrm{R}$ onkainen. 1984. M etals in Finnish liqueurs. Z eitschrift fur Lebensmittel Untersuchung und Forschung 178:393-396.

$\mathrm{H}$ einze, M. and $\mathrm{H}$.J. Fiedler 1981. Experimental planting of potash waste dumps. I. Communication: Pot experiments with trees and shrubs under various water and nutrient conditions. A rchiv fur Acker- und Pflanzenbau und Bodenkunde 25:315322.

Hiirsalmi, H. 1993. The role of natural small fruits in Finnish plant breeding. Aquilo. Ser. botanica 31:59-67.

H irvi, T. and E. H onkanen. 1984. The aroma of the fruit of sea buckthorn, $\mathrm{H}$ ippophae rhamnoides $\mathrm{L}$. Z eitschrift fur $L$ ebensmittel-U ntersuchung undForschung 179:387-388. (Hort. Abstr. $55: 2548)$.

H uang, Q. 1995. A review on H ippophae breeding in C hina. Proc. Intl. Sea Buckthorn Workshop D ec. 1995. Beijing, C hina.

I goshina, V.G., M.A. K orovina, V.E. Lobzhanidze, and I.P. Eliseev. 1987. D iversity of forms of $\mathrm{H}$ ippophaerhamnoi desL . in G eorgia. R astitelnye Resursy 23:190-196. (Plant Breeding Abstr. 57:11129).

I vanicka J. 1988. Propagation of unusual fruit crops from softwood cuttings under mist. Vedecke Prace $V$ yskumneho U stavu $O$ vocnych a $O$ krasnych $D$ revin $v B$ ojniciach 7:163-170. (H ort. Abstr. 59:3687).

K alinina, I.P. 1987. B reeding of sea buckthorn in the Altai, p. 76-87. In: A.B. Kryukov (ed.). Advances in agricultural science. M oscow, Russia. (Plant B reeding Abstr. 58:6090).

K luczynski, B. 1979. Suitability of selected tree and shrub species for the reclamation of ash wastes from power stations. Arboretum Kornickie 24:217-282.

K luczynski, B. 1989. Effects of sea buckthorn (H ippophae rhamnoides L.) cultivation on post-industrial wastelands in Po- 
land, p. 275-287. In: Proc. Intl. Symp. Sea Buckthorn. Xian, China. Oct. 1989.

K niga, N .M. 1989. Characteristics of rooting softwood cuttings of top and small fruit species in relation to natural photoperiod. Fiziologiya i Biokhimiya Kulturnykh Rastenii 21:403-409.

K och, H J. 1981. Cultivation of sea buckthorn for fruit production for the fruit processing industry. Gartenbau 28:175177.

K ondrashov, V.T. 1981. Structural elements of sea buckthorn productivity. Biologicheskie N auki 7:81-85.

K ondrashov, V.T. 1986a. Study of yield in $\mathrm{H}$ ippophaerhamnoi desin relation to breeding. Sostoyanie i perspektivy razvitiya kul'tury oblepikhi v N echernozemnoi zone RSFSR. M aterialy Soveshch., M oskva, 19 fevr., 1982. 23-27. (Plant B reeding Abstr. 57:11133).

K ondrashov, V.T. 1986b. The productivity of sea buckthorn varieties in relation to breeding. Sbornik N auchnykh Trudov, Vsesoyuznyi Nauchno-i I ssledovatelskii I nstitut Sadovodstvaimeni I. V. M ichurina 46:86-89. (Plant Breeding A bstr. 58:838).

K ondrashov, V.T . and V.N . K uimov. 1987. Vegetative propagation of $\mathrm{H}$ ippophae rhamnoi des Sadovodstvo 6:13-16. (H ort. Abstr. 58:2047).

K ondrashov, V.T. and E.P. Sokol ova. 1990. $\mathrm{N}$ ew wilt-resistant forms of $\mathrm{H}$ ippophae rhamnoides. Byulleten M oskovskogo O bshchestva I spytatelei Prirody, Biologicheskii 96:146-153. (Plant Breeding Abstr. 62:733).

K ostyrko, D.R . 1990. I ntroduction of useful food plants into the D onetsk Botanic $G$ arden of the $U$ krainian A cademy of Sciences. Introduktsiya i Akklimatizatsiya Rastenii 14:31-34. (H ort. Abstr. 61:3368).

K udritskaya, S.E., L.M . Zagorodskaya, and E.E. Shi shkina. 1989. C hemistry of N atural Compounds 25:724-725.

Kukenov, M.K.,F.D.D zhumagalieva, N .G. Tatimova, and S.B. Bespaev. 1982. Study of medicinal plant reserves and distribution atlas compilation in theK azakh-SSR U SSR and prospects of their use in public health service. I zvestiya Akademii $\mathrm{N}$ auk Kazakhskoi Ser Seriya Biologicheskaya 1:36.

K uznetsov, P.A. 1985. Effect of pre-planting treatment and plastic mulch on rooting of sea buckthorn hardwood cuttings and transplant quality. Biologicheskie Aspekty Introduktsii, Selektsii i Agrotekhniki Oblepikhi 1985:159-163. (H ort. Abstr. 56:8687).

Li, R. 1990. A brief introduction to the techniques of raising sea buckthorn seed- lings. $\mathrm{H}$ ippophae 1:18-19. (in Chinese).

Lian, Y. 1988. N ew discoveries of the genus $\mathrm{H}$ ippophae. Acta Phytotaxonomica Sinica 26:235-237.

Liu, S.W. and T.N. He. 1978. The genus $\mathrm{H}$ ippophae from the Q uin-Zang Plateau. Acta Phytotaxonomica 16:106-108 (in Chinese).

Loskutova, G.A ., V.G. Baikov, A.V.Starkov, and F.A. M edvedev. 1989. The composition of fatty acids from the lipids of $\mathrm{H}$ ippophaerhamnoi desL. fruits. Rastitelnye Resursy 25:97-103. (H ort. Abstr. 59:7303).

Lu, R. 1992. Sea buckthorn: A multipurpose plant species for fragile mountains. I ntl. Centre for I ntegrated M ountain D evelopment, Katmandu, $\mathrm{N}$ epal.

Lu, S. 1993. The chemical compositions of $\mathrm{H}$ ippophae fruits in China. Proc. 2nd Intl. Sea Buckthorn Symp. 338-412.

Mackay, J., L. Simon, and M. Laionde. 1987. Effect of substrate on the performance of in vitro propagated A Inus glutinosa clones inoculated with $\mathrm{Sp}+$ and Sp- Frankia strains. Plant and Soil 103:2131.

Magherini, R. 1986. Considerations on the biological potential of Hippophae rhamnoides L., p. 397-410. In: Atti. Convegno sulla Coltivazione delle Piante O fficinali, T rento, 9-10 0 ct. 1986. (H ort. Abstr. 58:6533).

Martemyanov, P.B. and T.V. K hromova. 1985. Agrotechnical measures for advancing woody plant growth. Byulleten' Glavnogo Botanicheskogo Sada 138:4548. (H ort. Abstr. 56:8066).

M ishulina, I.A. 1976. The effect of foliar nutrition with minor elementsof $\mathrm{H}$ ippophae rhamnoideson the fruit content of biologically active substances. Biol. Aktiv. Veshchestva Plodov i Yagod (1976) $97-$ 99. (H ort. Abstr. 48:320).

Montpetit, D. and M. Lalonde. 1988. In vitro propagation and subsequent nodulation of the actinorhizal $\mathrm{H}$ ippophae rhamnoides $\mathrm{L}$. Plant Cell, Tissue and $\mathrm{Or}$ gan Culture ( $\mathrm{N}$ etherlands) 15:189-200.

Morar, R., S. Cimpeanu, E. Morar, L. Marghitas, and Z. R ozalia. 1990. Results of theuse of certain phytotherapeutic preparations in the feeding of weaned piglets. Buletinul Institutului Agronomic Cluj$\mathrm{N}$ apoca. Seria Zootehnie si Medicina Veterinara 44:101-108.

Muller, K.D. 1993. Variability of selected characters of buckthorn clones and its importance, p. 51-56. In: Cultivation and utilization of wild fruit crops. Bernhard Thalacker Veriag Gmbh \& Co. (in German).
M yakushko, V.E., V.M. K osenko, and A.S. Bedritskii. 1986. H ippophaerhamnoi desin stands of gulley and ravine systems. L esnoe Khozyaistvo 10:30-34.

N ovruzov, E.N. and S.M. A sanov. 1983. Studies on the dynamics of ascorbic acid accumulation in sea buckthorn fruits. D oklady A kademii N aukAzerbaidzhanskoi SSR 39:59-63. (H ort. Abstr. 54:8057).

Olander, S. 1995. M echanical harvesting of Sea Buckthorn. Proc. I ntl. Sea Buckthorn Workshop 1995. Beijing, China.

Pan, R .Z., Z. Zhang, Y . M a, Z . Sun, and $B$. Deng. 1989. The distribution characters of sea buckthorn ( $\mathrm{H}$. rhamnoides L.) and its research progress in $\mathrm{C}$ hina. Proc. Intl. Symp. Sea Buckthorn, Xian, China. The Secretariat of Intl. Symp. Sea Buckthorn. p. 1-16.

Pearson, M.C. and J A. R ogers 1962. Biological flora of the British Isles. N 0. 85. H ippophaerhamnoi desL. . . E col. 50:501513.

Predeina, R.V. 1987. Fertilization of $\mathrm{H}$ ippophaerhamnoidesin the Altai region. Sadovodstvo 6:13-18. (H ort. Abstr. 58:2046)

R ousi, A . 1971. The genusH ippophaeL. A taxonomic study. Ann. B ot. Fennici 8:177227.

R ousi, A. and H. A ulin. 1977. Ascorbic acid content in relation to ripeness in fruit of six $\mathrm{H}$ ippophae rhamnoi des clones from Pyharanta, SW Finland. Ann. Agr. Fenn. 16:80-87.

Savkin, V.A . and S.M . M ukhamadiev. 1983. E ffect of branch detachment from sea buckthorn bushes on their regeneration and fruiting. Ekologiya Rastenii i Z hivotnykh Zapovednikov U zbekistana (1983) 2932. (H ort. Abstr. 54:8055)

Schroeder, W.R . 1988. Planting and establishment of shelterbelts in humid severewinter regions. Agr. Ecosystems Environ. 22/ 23:441-463.

Schroeder, W.R . 1990. Shelterbelt planting in the Canadian prairies, p. 35-43. In: Protective plantation technology. Publishing $\mathrm{H}$ ouse of Northeast Forestry $\mathrm{U}$ niv., $\mathrm{H}$ arbin, $\mathrm{C}$ hina.

Schroeder, W.R. 1995. I mprovement of conservation trees and shrubs. PFRA Shelterbelt Centre, Indian H ead, Sask., C anada. Supp. Rpt. 95-1.

Schroeder, W.R. and L.A. Alspach. 1995. $\mathrm{H}$ erbicideprogram at the PFRA Shelterbelt Centre. In: Proc. Western Forest Cons. N ursery Assn. Kearney, N ebraska.

Schroeder, W.R. and Y. Yao. 1995. Sea buckthorn: A promising multipurposecrop for Saskatchewan. Prairie F arm R ehabilita- 
tion Administration, A gricultureand AgriFood Canada.

Shchapov, N.S. and V.K. Kreimer. 1988. Experimental polyploids of sea buckthorn (H ippophae rhamnoides L.) I. Producing and identifying polyploids. I nvestiya Sibirskogo $O$ tdeleniyaA kademu N auk SSR Biologichesk I kh Nauk 6:111-117.

Shlyapnikova, A.S. 1985. Herbicides for the cultivation of black currants and sea buckthorn. Khimiya $v$ Sel'skom Khozyaistve 23:32-33. (Hort. Abstr. 56:7594).

Siabaugh, P.E. 1974. H ippophae rhamnoides - Common sea buckthorn. In: Seeds of woody plantsin theU nited States. C.S. Schopmeyer Tech. C o-ord. U SD AFS Agric. H dbk no. 450:446-447.

Smirnova, N.G. and N.I. Tikhomirova. 1980. Combined use of X-ray photography and the tetrazolium method for assessing seed viability. Byulleten' Glavnogo Botanicheskogo Sada 117:81-85. (H ort. Abstr. 51:6430).

Sokoloff, B.K., M . Funaoka, C.C. Fujisawa, E. Saelhof, D.B. R ani guchi, and C. Miller. 1961. An oncostatic factor present in the bark of $\mathrm{H}$ ippophae rhamnoides Growth 25:401-409.

Solonenko, L.P. and E.E. Shishkina. 1983. Proteins and amino acids in sea buckthorn fruits. Biologiya, K himiya i Farmakologiya O blepikhi 1983, 67-82.

Sun, Z. 1995. Exploitation and utilization of Sea Buckthorn ( $H$. rhamnoides $L$.) in China. N orthWest U niv.Publication, ShiAn, China.
Synge, P.M . 1974. D ictionary of gardening: A practical and scientific encyclopaedia of horticulture. 2 nd ed. Clarendon Press, 0 xford.

Trushechkin, V.G., G.V. Lobanova, S.A. Ostreiko, I.P. Kalinina, V.D. Bartenev, and V.M. Burdasov. 1973. The use of betachloroethylphosphonic acid for facilitating the detachment of $\mathrm{H}$ ippophae rhamnoi des and A ronia melanocarpa fruit in relation to mechanized harvesting. Sbornik $\mathrm{N}$ auchnykh Rabot, N auchnoIssledovatel'skii Zonalnyi Institut Sadovodstva Nechernozemnoi Polosy 6:168-173. (H ort. Abstr. 45:3902).

Varlamov, G.P. and V.G. Gabuniya. 1990. Picking sea buckthorn fruit by suction air stream. Traktory i sel'skokhozyaistvennye M ashiny 1:29-30

Vernik, R.S. and U.N. Zhapakova. 1986. Biology of seed germination in $\mathrm{H}$ ippophae rhamnoides. U zbekskii Biologicheskii Zhurnal 5:38-40.

Wahl berg, K . and N .J eppsson. 1990. D evelopment of cultivars and growing techniques for sea buckthorn, black chokeberry, L onicera, and Sorbus. Sveriges L antb bruksuniversitet. V erksamhetsberattel se Balsgaard (Sweden) 1990; 1988-1989:8093.

Wahl berg, K . and N .J eppsson. 1992. D evelopment of cultivars and growing techniques for sea buckthorn, black chokeberry, honeysuckle and rowan. Verksamhetsberaettelse Balsgaard (Sweden) 1992:86-100.

Wang, S. 1990. Studies on the chemical components in fruits of $\mathrm{H}$ ippophae rhamnoides Forest Res. 3:98-102.

Wolf, D. and F. Wegert. 1993. Experience gained in the harvesting and utilization of sea buckthorn, p. 23-29. In: Cultivation and utilization of wild fruit crops. B ernhard Thalacker Veriag Gmbh \& Co. (in German).

$\mathrm{Xu}, \mathrm{M}$. 1994. The medical research and exploitation of sea buckthorn. $\mathrm{H}$ ippophae 7:32-84 (in Chinese).

Y ao, Y. and P.M.A. Tigerstedt. 1994. Genetic diversity in $\mathrm{H}$ ippophae $\mathrm{L}$. and its use in plant breeding. Euphytica 77:165-169.

Y ao, Y . and P.M .A. Tigerstedt. 1995. Geographical variation of growth rhythm, height, and hardiness and their relations in $\mathrm{H}$ i ppophaerhamnoi des J . A mer. Soc. H ort. Sci. 120:691-698.

Y ao, Y.,P.M .A. Tigerstedt, and P.J oy. 1992. Variation of vitamin $C$ concentration and character correlation between and within natural sea buckthorn (H ippophae rhamnoides L.) populations. Acta Agr. Scand. 42:12-17.

Zhong, C., X. Zhang, and R. Shu. 1989. Clinical effects of cosmetics with sea buckthorn extracts, p. 322-324. I n: Proc. Intl. Symp. Sea Buckthorn, Xian, China, O ct. 1989. TheSecretariat of I ntl. Symp. on Sea Buckthorn.

Zhou, Y., D. R uan, B. Y ang, and S. Wang. 1991. A study on vitamin C content of $\mathrm{H}$ ippophaerhamnoi desfruit and its changing roles. Forest Res. 4:345-349.

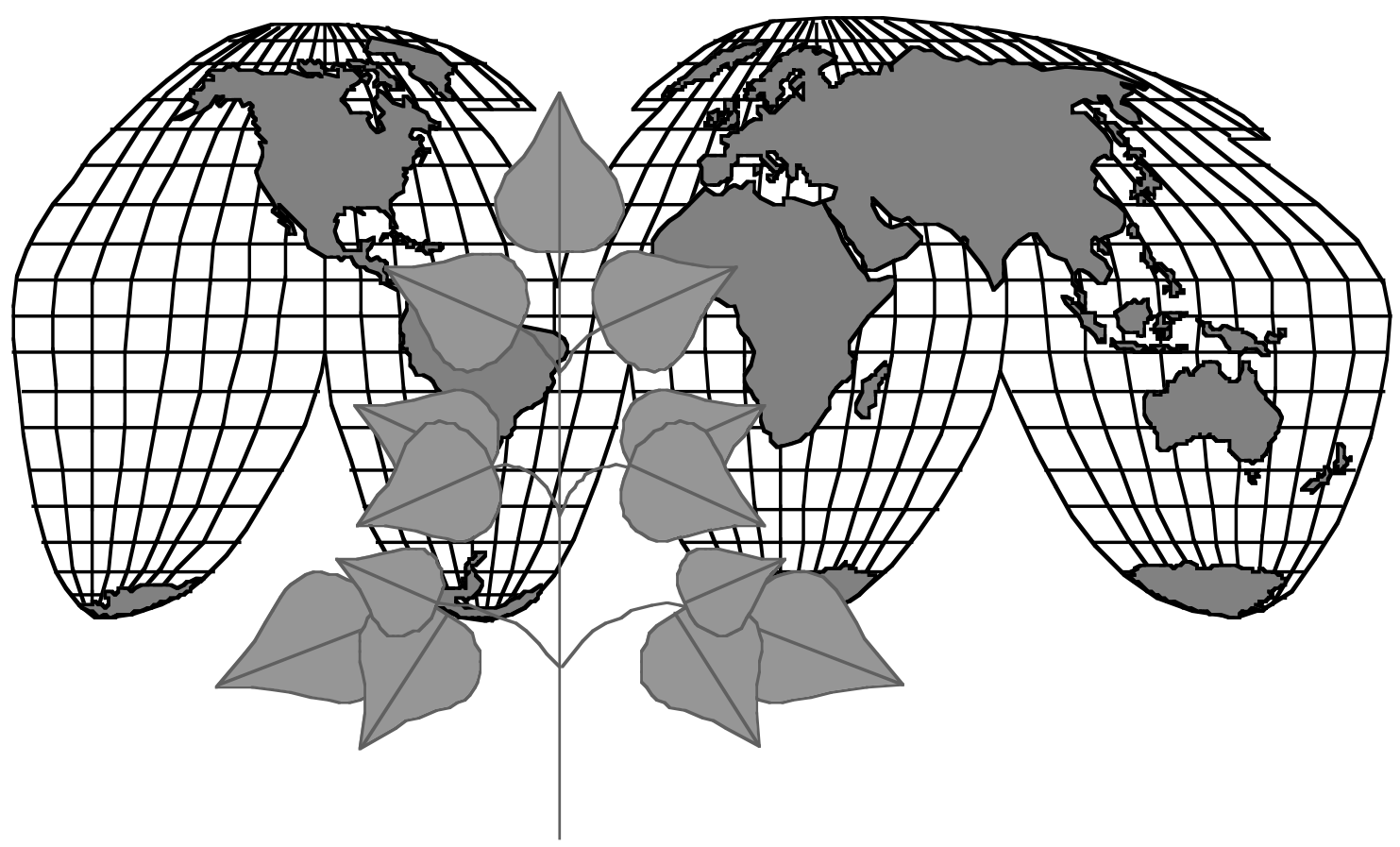

